\title{
Effect of forage/concentrate ratio and soybean oil supplementation on milk yield, and composition from Sarda ewes
}

\author{
Marcello MeLE ${ }^{a *}$, Arianna BUCCIONI ${ }^{\mathrm{b}}$, Francesco PETACCHI ${ }^{\mathrm{c}}$, Andrea \\ SERRA $^{\text {a }}$, Sebastiano BANNI ${ }^{\mathrm{c}}$, Mauro ANTONGIOVANNI ${ }^{\mathrm{b}}$, Pierlorenzo \\ SECCHIARI ${ }^{\mathrm{a}}$ \\ a Dipartimento di Agronomia e Gestione dell'Agroecosistema, Sezione di Scienze Zootecniche, \\ Università di Pisa, Italy \\ ${ }^{\mathrm{b}}$ Dipartimento di Scienze Zootecniche, Università di Firenze, Italy \\ ${ }^{\mathrm{c}}$ Dipartimento di Biologia Sperimentale, Università di Cagliari, Italy
}

(Received 28 July 2005 - Accepted 21 March 2006)

\begin{abstract}
Sixteen lactating Sarda ewes were fed four diets differing in the forage/concentrate ratio (two diets 75/25, two diets 60/40, on a DM basis) and in soybean oil supplementation (two diets with $100 \mathrm{~g} \cdot \mathrm{d}^{-1}$ oil, two diets with no oil), in a $4 \times 4$ Latin square design. The inclusion of soybean oil in the diet resulted in a significant increase of both daily milk yield and fat corrected milk $(P \leq 0.01)$, while diets with higher concentrate content resulted in lower levels of milk production $(P \leq 0.05)$. Milk fat content did not differ among treatments, while milk fat yield was increased when ewes consumed oil added diets $(P<0.01)$. Milk protein content was lower when oil was added to the diet $(P \leq 0.01)$, which was attributed to a dilution effect, while milk protein secretion did not differ among treatments. Dietary soybean oil modified the milk fatty acid composition towards a lower level of medium chain and saturated fatty acid and a higher level of PUFA and CLA, confirming how an adequate dietary strategy can broadly modify sheep milk quality towards a more desirable composition for human health. In particular, soybean oil in the diet resulted in a significant increase of both rumenic acid (cis-9, trans-11 CLA) and vaccenic acid (trans-11 $\left.\mathrm{C}_{18: 1}\right)$ in milk fat. Interactions among forage and oil resulted in a significant increase in rumenic acid and vaccenic acid with the $\mathrm{HF} / \mathrm{O}$ diet and trans-10 $\mathrm{C}_{18: 1}$ and trans-10, cis-12 CLA with the LF/O diet, probably due to a shift in rumen biohydrogenation of linoleic acid.
\end{abstract}

\section{CLA / trans fatty acid / sheep milk / soybean oil}

Résumé - Effet du rapport fourrage/concentré et de l'addition d'huile de soja sur la production et la composition du lait de brebis de race Sarde. Seize brebis de race Sarde ont été alimentées, selon un schéma en carré latin $4 \times 4$, avec 4 rations différant par leur rapport fourrage/concentré (75/25 ou 60/40 par rapport à la matière sèche) et par l'addition ou non de $100 \mathrm{~g}$

*Corresponding author: mmele@agr.unipi.it 
d'huile de soja par jour (factoriel $2 \times 2$ ). L'inclusion d'huile de soja dans les rations a permis une augmentation significative de la production laitière $(P<0,01)$ contrairement à ce qui a été observé avec les rations les plus riches en concentré $(P<0,05)$. La teneur en matière grasse du lait n'a pas été différente entre les traitements, mais la production journalière de matière grasse a été augmentée par les rations enrichies en huile de soja $(P<0,01)$. La teneur en protéines du lait a été plus basse avec les rations enrichies en huile (par effet de dilution), mais la sécrétion journalière de protéines du lait n'a pas été différente entre les traitements. L'huile de soja a entraîné une modification de la composition en acides gras du lait : la proportion d'acides gras à chaîne moyenne et saturés a diminué alors que la proportion des acides gras polyinsaturés (PUFA) et des acides gras linoléiques conjugués (CLA) a augmenté. L'apport d'huile de soja dans la ration constitue donc un moyen intéressant d'obtenir une composition du lait convenant mieux à la santé humaine. L'huile de soja a permis une augmentation significative, dans la matière grasse, de l'acide ruménique (RA, cis-9, trans-11 CLA) et de l'acide vaccénique (VA, trans-11 C18:1). Les interactions entre les niveaux du fourrage et l'apport d'huile ont été significatives pour RA et VA dans la ration la plus riche en fourrage et enrichie en huile $(\mathrm{HF} / \mathrm{O})$ et pour les acides trans-10 $\mathrm{C}_{18: 1}$ et trans-10, cis-12 CLA dans la ration la plus pauvre en fourrage et enrichie en huile (LF/O), à la suite, probablement, d'un changement de l'hydrogénation ruminale de l'acide linoléique.

CLA / acide gras trans / lait de brebis / huile de soja

\section{INTRODUCTION}

Ruminant diets are commonly supplemented with oils or fats to meet the high energy requirements of early lactation and/or to address the composition of milk fat towards the enrichment in beneficial fatty acids.

Information from the literature on the effect of dietary lipid on cow milk fat content is highly variable according to the nature of the fat, the level of fat supplementation and the nature of the basal diet $[10,38]$. In dairy cows, a marked depression of milk fat yield has been observed when low forage diets were supplemented with unprotected oil rich in polyunsaturated fatty acids (PUFA) [34]. The milk fat depression (MFD) has been attributed to a shift of rumen biohydrogenation pathways of dietary PUFA towards trans-10, cis-12 $\mathrm{C}_{18: 2}$ and trans-10 $\mathrm{C}_{18: 1}$ fatty acids, which are potent inhibitors of mammary lipogenic enzymes [3,4].

The effects of feeding of calcium soaps of fatty acids $[1,9,32,36,42]$ and unprotected oils from plants and animal fats $[19,23,46]$ to dairy ewes have been studied and recently reviewed by Schmidely and Sauvant [38]. However, no consistent data are available on the effect of the interactions between unprotected plant oil and forage/concentrate ratio in the diet.

The aim of the present work was to get novel information on the effect of unprotected soybean oil in the diets of Sarda ewes, upon the milk fat yield and composition, by varying the forage/concentrate ratio of the diet.

\section{MATERIALS AND METHODS}

\subsection{Animals}

Sixteen Sarda ewes, average body weight $43.5 \pm 3.8 \mathrm{~kg}$, at their third lambing and mid lactation (fourth month) were allotted to single boxes on a peat litter, in order to be able to control performances and intakes individually.

\subsection{Diets}

The 4 experimental diets differed in terms of forage/concentrate ratio and oil supplementation (diet composition expressed as the percentage of dry matter intake):

- A diet with high forage and no oil $(\mathrm{HF} / \mathrm{NO})$, made up of lucerne hay $(75 \%)$, 
Table I. Average composition of the four experimental diets (on a DM basis).

\begin{tabular}{|c|c|c|c|c|}
\hline & \multicolumn{4}{|c|}{ Diets } \\
\hline & $\mathrm{HF} / \mathrm{NO}$ & $\mathrm{HF} / \mathrm{O}$ & $\mathrm{LF} / \mathrm{NO}$ & $\mathrm{LF} / \mathrm{O}$ \\
\hline $\mathrm{DM}$ & 85.6 & 86.1 & 85.7 & 86.1 \\
\hline $\mathrm{CP}$ & 15.6 & 15.5 & 15.6 & 15.2 \\
\hline EE & 1.8 & 5.5 & 1.6 & 5.2 \\
\hline NDF & 45.2 & 44.7 & 39.5 & 39.3 \\
\hline $\mathrm{ADF}$ & 28.0 & 27.6 & 23.4 & 23.2 \\
\hline ADL & 7.5 & 7.4 & 6.2 & 6.1 \\
\hline NSC & 30.5 & 27.5 & 36.8 & 34.0 \\
\hline Ash & 7.0 & 6.8 & 6.4 & 6.2 \\
\hline NEL (Mcal $\left.\cdot \mathrm{kg}^{-1} \mathrm{DM}\right)$ & 1442 & 1575 & 1533 & 1680 \\
\hline $\mathrm{MP}\left(\mathrm{g} \cdot \mathrm{kg} \mathrm{DM}{ }^{-1}\right)$ & 108.2 & 103.9 & 112.5 & 107.1 \\
\hline $\mathrm{F} / \mathrm{C}$ & $75 / 25$ & $75 / 25$ & $60 / 40$ & $60 / 40$ \\
\hline
\end{tabular}

Diets: $\mathrm{HF} / \mathrm{NO}=$ high forage no oil; $\mathrm{HF} / \mathrm{O}=$ high forage with oil; $\mathrm{LF} / \mathrm{NO}=$ low forage no oil; $\mathrm{LF} / \mathrm{O}=$ low forage with oil. NSC: non structural carbohydrates. NEL: net energy lactation. MP: metabolisable protein. $\mathrm{F} / \mathrm{C}$ : forage/concentrate ratio.

barley meal (20\%) and soybean meal (5\%); - A diet with high forage and with oil $(\mathrm{HF} / \mathrm{O})$, made up of lucerne hay $(75 \%)$, barley meal (15\%) and soybean meal (6\%) and soybean oil (4\%);

- A diet with low forage and no oil (LF/NO), made up of lucerne hay $(60 \%)$, barley meal (35\%) and soybean meal (5\%); - A diet with low forage and with oil (LF/O), made up of lucerne hay $(60 \%)$, barley meal (30\%) and soybean meal $(6 \%)$ and soybean oil (4\%).

Lucerne hay was fed separately twice a day, controlling the actual intakes of both forage and concentrate.

Table I depicts the chemical composition and energy content of the 4 diets. Crude protein, ether extract and ash were determined according to AOAC methods [2]. The fibre fractions were analysed after Goering and van Soest [17]. Net energy for lactation and metabolisable protein were estimated by the CNCPS system, modified for sheep [8]. Table II reports the fatty acid composition of the soybean oil added to $\mathrm{HF} / \mathrm{O}$ and $\mathrm{LF} / \mathrm{O}$ diets.

\subsection{Experimental design}

A $4 \times 4$ Latin square experimental design with factorial arrangement of treatments and 4 replicates per diet was used as the most suitable to 16 animals. Each experimental period lasted one week and was preceded by an adaptation period of two weeks, meant to let the rumen microbes get accustomed to the changed diet.

\subsection{Body weights and blood samples}

The animals were individually weighed and blood samples were taken from the jugular vein at the start and at the end of each experimental period, always at the same time $(8: 30 \mathrm{am})$ after the morning meal and milking. The blood samples were collected in a vacuum tube with sodium heparin, immediately chilled down to $4{ }^{\circ} \mathrm{C}$ and transported to the lab, then centrifuged (3000 rpm, $15 \mathrm{~min}, 4{ }^{\circ} \mathrm{C}$ ). The separated plasma was analysed by spectrophotometry for urea, using a current commercial kit (UREA-S, Roche Diagnostics, GmbH, Mannheim, Germany), as a convenient measure of protein status.

Table II. Fatty acid composition of the soybean oil added to the supplemented diets.

\begin{tabular}{lc}
\hline Fatty acids & $\mathrm{g} \cdot 100 \mathrm{~g}^{-1} \mathrm{FA}$ \\
\hline $\mathrm{C}_{14: 0}$ & 0.3 \\
$\mathrm{C}_{16: 0}$ & 15.0 \\
$\mathrm{C}_{16: 1}$ & 0.1 \\
$\mathrm{C}_{18: 0}$ & 4.1 \\
$\mathrm{C}_{18: 1}$ cis 9 & 22.0 \\
$\mathrm{C}_{18: 2} \mathrm{n}-6$ & 50.5 \\
$\mathrm{C}_{18: 3} \mathrm{n}-3$ & 6.7 \\
$\mathrm{C}_{20: 0}$ & 0.7 \\
$\mathrm{C}_{20: 1} \mathrm{n}-9$ & 0.5 \\
\hline
\end{tabular}




\subsection{Milk yield and milk sample analyses}

The animals were milked twice daily (at 8:00 $\mathrm{h}$ and 20:00 h) and weekly milk samples of the morning and of the afternoon from individual ewes were collected. Milk samples were gathered in a single sample according to the morning and afternoon yield. Milk samples were analysed for fat by the official AOAC methods [2]; milk proteins and lactose contents were determined by infrared analysis (Milkoscan 133 B, Italian Foss Electric, Padova, Italy); somatic cell count (SCC) was performed by means of a Fossomatic 215 (Foss Electric, DK-3400, Hillerod, Denmark). The SCC data were transformed into a linear score according to Wiggans and Shook [44]. Rennet clotting time (r), rate of curd firming $\left(\mathrm{K}_{20}\right)$, and curd firmness after $30 \mathrm{~min}$ $\left(A_{30}\right)$ were also measured on a Formagraph apparatus, [15], at the end of each experimental period. Milk production was standardised as Fat-Corrected Milk (FCM) at $6.5 \%$ fat, according to the following formula: $\mathrm{FCM}=\mathrm{M}(0.37+0.097 \mathrm{~F})$, where $\mathrm{M}$ is milk yield $(\mathrm{kg})$ and $\mathrm{F}$ is milk fat percentage [35].

\subsection{Fatty acid analysis}

An aliquot of weekly milk samples was stored at $-20{ }^{\circ} \mathrm{C}$ until fat extraction for fatty acid analysis. Milk fat extraction was performed according to the Rose-Gottlieb method [2] modified by Secchiari et al. [39]. Briefly, ammonia 25\% (0.4 mL), ethyl alcohol 95\% (1 mL) and hexane ( $5 \mathrm{~mL}$ ) were added to $2 \mathrm{~g}$ of a raw milk sample. After being vortexed, the samples were centrifuged at $3000 \mathrm{rpm}$ and $2{ }^{\circ} \mathrm{C}$. After phase separation, the upper layer was collected. The extraction was repeated a second time using ethyl alcohol 95\% (1 mL) and hexane $(5 \mathrm{~mL})$; the samples were centrifuged at $3000 \mathrm{rpm}$ and the upper layer was collected. A third extraction was repeated using $5 \mathrm{~mL}$ of hexane; the samples were centrifuged at $3000 \mathrm{rpm}$ and the upper layer was collected. The extracted fat was dried at $35{ }^{\circ} \mathrm{C}$ by means of a rotary evaporator device, weighed and finally dissolved in hexane. Methyl esters of medium and long chain fatty acids were prepared by the alkali catalysed trans-methylation procedure of Christie [14], with nonadecanoic acid methyl ester (Sigma Chemical Co., St. Louis, MO, USA) as the internal standard. Medium and long chain fatty acid (MCFA and LCFA) composition was determined by gas chromatography using a ThermoQuest (Milan, Italy) gas-chromatograph apparatus equipped with an FID and a high polar fused silica capillary column (Chrompack CP-Sil 88 Varian, Middelburg, Netherland; $100 \mathrm{~m} \times 0.25$ i.d.; film thickness $0.20 \mu \mathrm{m}$ ). Helium was used as the carrier gas at a flow of $1 \mathrm{~mL} \cdot \mathrm{min}^{-1}$. The split ratio was 1:100. An aliquot of the sample was injected under the following GC conditions: the oven temperature was programmed at $120^{\circ} \mathrm{C}$ and held for $1 \mathrm{~min}$, then increased to $180{ }^{\circ} \mathrm{C}$ at a rate of $5^{\circ} \mathrm{C} \cdot \mathrm{min}^{-1}$, held for $18 \mathrm{~min}$, increased to $200^{\circ} \mathrm{C}$ at $2^{\circ} \mathrm{C} \cdot \mathrm{min}^{-1}$, held for $1 \mathrm{~min}$, increased to $230{ }^{\circ} \mathrm{C}$ at a rate of $2{ }^{\circ} \mathrm{C} \cdot \mathrm{min}^{-1}$ and held for $19 \mathrm{~min}$. The injector temperature was set at $270{ }^{\circ} \mathrm{C}$, whereas the detector temperature was set at $300{ }^{\circ} \mathrm{C}$. Short chain fatty acid composition (SCFA, from $\mathrm{C}_{4}$ to $\mathrm{C}_{8}$ ) was determined according to Molkentin and Precht [28] on a second aliquot of the same sample: $25 \mathrm{mg}$ of lipid extract were transesterified with $0.2 \mathrm{~mL}$ of methanol $\mathrm{KOH}$ $2 \mathrm{~N}$. Fatty acid methyl esters (FAME) were dissolved in hexane containing methyl valerate as the internal standard. The butyric acid content was calculated by a regression curve based on 5 response factors obtained by increasing the $\mathrm{C}_{4} / \mathrm{C}_{5}$ ratio (the ratio varied from $0.15 / 0.40 \mathrm{mg} \cdot \mathrm{mL}^{-1}$ to $1.20 / 0.40 \mathrm{mg} \cdot \mathrm{mL}^{-1}$ ). Fatty acids from $\mathrm{C}_{6}$ to $\mathrm{C}_{8}$ were quantified using methyl 
valerate as the internal standard. The SCFA content was determined using the gaschromatograph apparatus described above and another temperature gradient programme $\left(40{ }^{\circ} \mathrm{C}\right.$ held for $4 \mathrm{~min}$, increased to $180{ }^{\circ} \mathrm{C}$ at $5{ }^{\circ} \mathrm{C} \cdot \mathrm{min}^{-1}$ ). The determination of cis and trans $\mathrm{C}_{18: 1}$ isomers was performed on a third aliquot of the same sample at $175^{\circ} \mathrm{C}$ (isothermal step) for $65 \mathrm{~min}$, using the same capillary column.

Individual FAME were identified by comparison to a standard mixture of 37 Component FAME Mix (Supelco, Bellefonte PA, USA). The standards PUFA2 , non conjugated $\mathrm{C}_{18: 2}$ isomer mixture, individuals cis-5,8,11,14,17 $\mathrm{C}_{20: 5}$; cis-4,7,10,13,16,19 $\mathrm{C}_{22: 6}$ (Supelco, Bellefonte PA, USA); cis-6,9,12 $\mathrm{C}_{18: 3}$ and cis9,12,15 $\mathrm{C}_{18: 3}$ (Matreya Inc., Pleasant Gap PA, USA) were used to identify polyunsaturated fatty acids. The identification of isomers of $\mathrm{C}_{18: 1}$ was based on commercial standard mixtures (Supelco, Bellefonte PA, USA) and published isomeric profiles [45]. All methods using peak normalisation and expressing the results in relative percentage of the area of the analysed peaks are subjected to an overestimation because the areas of small peaks are not considered, so to avoid this problem, nonadecanoic acid was used as the internal standard. All the results concerning the milk fatty acid composition are expressed as $\mathrm{g}$ per $100 \mathrm{~g}$ of fat.

The different conjugated linoleic acid (CLA) isomers were separated and quantified by a silver ion HPLC column (Chromspher 5 lipids, $250 \times 4.6 \mathrm{~mm}$, Varian Inc, Turin, Italy), using the procedure reported in Sehat et al. [41]. CLA isomers were eluted using a fresh mixture of acetonitrile $0.1 \%(\mathrm{v} / \mathrm{v})$ in hexane at a flow of $1 \mathrm{~mL} \cdot \mathrm{min}^{-1}$. The injection loop was $50 \mu \mathrm{L}$ and UV detection was performed at a wavelength of $233 \mathrm{~nm}$. Since a reliable internal standard for CLA is not yet available, the quantitative measurements were performed through a calibration curve, using high purity individual cis-9, trans-11 and trans-10, cis-12 CLA (Matreya Inc., Pleasant Gap PA, USA). A CLA standard mixture (Sigma Chemical Co., St. Louis, MO, USA), and a published isomeric profile [24] were also used to help to identify the CLA isomers in ovine milk.

\subsection{Statistical analysis}

Data were processed by the GLM procedure of SAS [37] using a linear model that included forage level, oil supplementation, replicate, ewe within replicate, period within replicate, forage $\times$ oil interaction and residual error. Data are reported as least squares means \pm SEM. Overall differences between treatment means and interaction for level of forage and oil were considered to be significant for $P \leq 0.05$.

\section{RESULTS}

Average dry matter intakes (DMI) did not differ between experimental groups and met the ewes' energy requirements in any case. In fact, body weights remained practically unchanged throughout the whole trial (Tab. III).

The oil supplemented diets resulted in significant increases in both milk yield and FCM, whereas the low forage diets depressed milk yield. The milk fat concentration was not different among treatments, while the fat yield was higher. The protein content was lower with the oil diets, probably due to a dilution effect; whereas the milk protein yield did not differ. However, the forage $\times$ oil interaction resulted in a significant increase of plasma urea content for the LF/O diet (Tab. III).

The milk casein content as well as the rheological parameters did not differ significantly among the diets. This means that the cheesing capability of milk from the different groups was not different.

On the contrary, the composition of the diets had a marked effect on the fatty acid 
Table III. Effect of forage/concentrate ratio and soybean oil supplementation on dry matter intake, body weight gain, milk fat yield and composition, milk cheese ability and plasma urea content.

\begin{tabular}{|c|c|c|c|c|c|c|c|c|}
\hline & \multicolumn{4}{|c|}{ Diets $^{1}$} & \multirow[b]{2}{*}{ SEM } & \multicolumn{3}{|c|}{ Effect } \\
\hline & $\mathrm{HF} / \mathrm{NO}$ & $\mathrm{HF} / \mathrm{O}$ & $\mathrm{LF} / \mathrm{NO}$ & $\mathrm{LF} / \mathrm{O}$ & & For & Oil & For $\times$ oil \\
\hline DMI $\left(\mathrm{kg} \cdot \mathrm{d}^{-1}\right)$ & 2.10 & 2.08 & 1.91 & 1.93 & 0.22 & & & \\
\hline Body weight (kg) & 44.2 & 44.6 & 44.5 & 44.0 & 0.25 & & & \\
\hline Milk yield $\left(\mathrm{g} \cdot \mathrm{d}^{-1}\right)$ & 1017.3 & 1035.8 & 983.3 & 1006.9 & 10.9 & $*$ & $* *$ & \\
\hline $6.5 \%$ Fat corrected milk $\left(\mathrm{g} \cdot \mathrm{d}^{-1}\right)$ & 859.7 & 946.6 & 802.1 & 932.1 & 27.3 & & $* *$ & \\
\hline Milk fat content $(\%)$ & 5.90 & 5.96 & 5.94 & 5.99 & 0.12 & & & \\
\hline Milk fat yield $\left(\mathrm{g} \cdot \mathrm{d}^{-1}\right)$ & 53.7 & 59.4 & 50.2 & 58.5 & 1.71 & & $* *$ & \\
\hline Milk protein content $(\%)$ & 5.09 & 4.93 & 5.25 & 4.96 & 0.04 & & $* *$ & \\
\hline Milk protein yield $\left(\mathrm{g} \cdot \mathrm{d}^{-1}\right)$ & 46.4 & 49.5 & 44.5 & 48.6 & 1.46 & & & \\
\hline Milk casein content $(\%)$ & 4.54 & 4.52 & 4.61 & 4.50 & 0.09 & & & \\
\hline Lactose content $(\%)$ & 4.81 & 4.85 & 4.80 & 4.84 & 0.02 & & & \\
\hline SCC (linear score) & 4.84 & 4.71 & 5.03 & 4.69 & 0.06 & & & \\
\hline $\mathrm{R}$ (min) & 13.0 & 14.4 & 15.2 & 13.4 & 0.46 & & & \\
\hline $\mathrm{A}_{30}(\mathrm{~mm})$ & 41.2 & 42.8 & 42.3 & 39.1 & 1.26 & & & \\
\hline $\mathrm{K}_{20}(\min )$ & 1.71 & 1.46 & 1.61 & 1.57 & 0.12 & & & \\
\hline Plasma urea $\left(\mathrm{mg} \cdot \mathrm{dL}^{-1}\right)$ & 54.1 & 55.4 & 48.5 & 63.8 & 2.72 & & $* *$ & $*$ \\
\hline
\end{tabular}

$*: P<0.05$; **: $P<0.01$. DMI: dry matter intake. ${ }^{1}$ Diets: $\mathrm{HF} / \mathrm{NO}=$ high forage no oil; $\mathrm{HF} / \mathrm{O}=$ high forage with oil; $\mathrm{LF} / \mathrm{NO}=$ low forage no oil; $\mathrm{LF} / \mathrm{O}=$ low forage with oil. SCC: somatic cell count. R: rennet clotting time. $\mathrm{A}_{30}$ : curd firmness after $30 \mathrm{~min} . \mathrm{K}_{20}$ : rate of curd firming.

profile of milk fat (Tab. IV). The oil supplemented diets depressed both SCFA and MCFA, with the only exception of butyric acid, which was increased. The low forage diets increased significantly $\mathrm{C}_{10}-\mathrm{C}_{17}$ FA. All the cis and trans $\mathrm{C}_{18: 1}$ isomers were increased by the inclusion of soybean oil in the diet (Tab. IV), while the forage effect was significant only for trans-10 $\mathrm{C}_{18: 1}$; vaccenic acid (trans- $11 \mathrm{C}_{18: 1}$ ); trans$12 \mathrm{C}_{18: 1} ;$ cis-12 $\mathrm{C}_{18: 1} ;$ cis-14 $\mathrm{C}_{18: 1}$ and cis$15 \mathrm{C}_{18: 1}$. In some cases a significant forage $\times$ oil interaction was also observed: the $\mathrm{LF} / \mathrm{O}$ diet, in fact, resulted in higher levels of trans-10 $\mathrm{C}_{18: 1}$, trans- $12 \mathrm{C}_{18: 1}$ and cis-12 $\mathrm{C}_{18: 1}$, while the HF/O diet led to the highest levels of vaccenic acid, cis-11 $\mathrm{C}_{18: 1}$ and cis-15 $\mathrm{C}_{18: 1}$.

Both oil supplementation and forage level affected the amounts of linoleic $\left(\mathrm{C}_{18: 2}\right.$ n-6) and linolenic acids $\left(\mathrm{C}_{18: 3} \mathrm{n}-3\right)$, with opposite effects. When soybean oil was included in the diet, the level of linoleic acid increased, but to a different extent, depending on the interaction with the level of dietary forage (Tab. IV). In the case of LF diets, in fact, the inclusion of soybean oil increased linoleic acid in milk fat by $3 \%$, while when the oil was added to the HF diets, the level of linoleic acid increased by more than $20 \%$.

The alfa-linolenic acid content was positively affected by the forage/concentrate ratio, and negatively by the soybean oil supplementation (Tab. IV).

The CLA content of milk from ewes fed the diets without lipid supplementation was below $1 \%$ of total lipids $(0.5 \%$ and $0.7 \%$ respectively for $\mathrm{HF} / \mathrm{NO}$ and LF/NO diets). The levels of CLA were 
Table IV. Effect of forage/concentrate ratio and soybean oil supplementation on milk fatty acid composition (g per $100 \mathrm{~g}$ total lipids).

\begin{tabular}{|c|c|c|c|c|c|c|c|c|}
\hline & \multicolumn{4}{|c|}{ Diets $^{1}$} & \multirow[b]{2}{*}{ SEM } & \multicolumn{3}{|c|}{ Effect } \\
\hline & $\mathrm{HF} / \mathrm{NO}$ & $\mathrm{HF} / \mathrm{O}$ & $\mathrm{LF} / \mathrm{NO}$ & $\mathrm{LF} / \mathrm{O}$ & & For & Oil & For $\times$ Oil \\
\hline C4:0 & 3.55 & 4.16 & 3.88 & 4.12 & 0.157 & & * & \\
\hline C6:0 & 2.60 & 1.86 & 2.64 & 2.26 & 0.145 & & $* *$ & \\
\hline C8:0 & 2.70 & 1.64 & 2.86 & 2.13 & 0.207 & & $* *$ & \\
\hline $\mathrm{C} 10: 0$ & 6.26 & 2.57 & 7.90 & 3.94 & 0.291 & $* *$ & $* *$ & \\
\hline C12:0 & 3.87 & 1.65 & 5.06 & 2.45 & 0.172 & $* *$ & $* *$ & \\
\hline C14:0 & 8.99 & 6.26 & 11.04 & 7.59 & 0.334 & $* *$ & $* *$ & \\
\hline C14:1 cis-9 & 0.12 & 0.07 & 0.15 & 0.09 & 0.009 & $* *$ & $* *$ & \\
\hline C16:0 & 23.43 & 17.40 & 26.73 & 19.88 & 0.625 & $* *$ & $* *$ & \\
\hline C16:1 cis-9 & 0.93 & 0.60 & 1.07 & 0.71 & 0.025 & $* *$ & $* *$ & \\
\hline $\mathrm{C} 17: 0$ & 0.63 & 0.42 & 0.54 & 0.40 & 0.022 & * & $* *$ & \\
\hline $\mathrm{C} 18: 0$ & 5.68 & 7.37 & 5.92 & 7.73 & 0.276 & & $* *$ & \\
\hline C18:1 trans -6 - trans -8 & 0.05 & 0.36 & 0.06 & 0.37 & 0.011 & & $* *$ & \\
\hline C18:1 trans -9 & 0.10 & 0.44 & 0.12 & 0.36 & 0.015 & & $* *$ & $* *$ \\
\hline C18:1 trans -10 & 0.13 & 0.60 & 0.23 & 0.87 & 0.025 & $* *$ & $* *$ & $* *$ \\
\hline C18:1 trans-11 & 0.76 & 7.68 & 0.75 & 5.96 & 0.192 & $* *$ & $* *$ & $* *$ \\
\hline C18:1 trans -12 & 0.07 & 0.36 & 0.07 & 0.45 & 0.020 & * & $* *$ & * \\
\hline C18:1 trans -13 & 0.15 & 0.33 & 0.13 & 0.38 & 0.016 & & $* *$ & \\
\hline Total C18:1 trans & 1.24 & 9.83 & 1.39 & 8.39 & 0.023 & $* *$ & $* *$ & $* *$ \\
\hline C18:1 cis-9 & 10.45 & 13.76 & 11.07 & 13.01 & 0.28 & & $* *$ & $*$ \\
\hline $\mathrm{C} 18: 1$ cis 11 & 0.21 & 0.38 & 0.24 & 0.32 & 0.012 & & $* *$ & $* *$ \\
\hline $\mathrm{C} 18: 1$ cis 12 & 0.14 & 0.63 & 0.18 & 0.87 & 0.037 & $* *$ & $* *$ & * \\
\hline $\mathrm{C} 18: 1$ cis 13 & 0.04 & 0.10 & 0.04 & 0.10 & 0.003 & & $* *$ & \\
\hline $\mathrm{C} 18: 1$ cis 14 & 0.17 & 0.32 & 0.19 & 0.38 & 0.013 & $* *$ & $* *$ & \\
\hline $\mathrm{C} 18: 1$ cis 15 & 0.02 & 0.09 & 0.03 & 0.05 & 0.001 & $* *$ & $* *$ & $* *$ \\
\hline Total C18:1 cis & 11.03 & 15.27 & 11.76 & 14.74 & 0.003 & & $* *$ & \\
\hline C18:2 n-6 & 2.00 & 2.56 & 2.53 & 2.63 & 0.069 & $* *$ & $* *$ & $* *$ \\
\hline C18:3 n-3 & 1.06 & 0.67 & 0.87 & 0.53 & 0.026 & $* *$ & $* *$ & \\
\hline & & & Ratios & & & & & \\
\hline $14: 1 / 14: 0+14: 1$ & 0.013 & 0.011 & 0.013 & 0.011 & 0.0006 & & $* *$ & \\
\hline $16: 1 / 16: 0+16: 1$ & 0.038 & 0.033 & 0.038 & 0.034 & 0.0007 & & $* *$ & \\
\hline $18: 1 / 18: 0+18: 1$ & 0.65 & 0.65 & 0.65 & 0.63 & 0.004 & & & \\
\hline $\mathrm{RA} / \mathrm{VA}+\mathrm{RA}$ & 0.37 & 0.29 & 0.40 & 0.26 & 0.011 & & $* *$ & $*$ \\
\hline
\end{tabular}

${ }^{1}$ Diets: $\mathrm{HF} / \mathrm{NO}=$ high forage no oil; $\mathrm{HF} / \mathrm{O}=$ high forage with oil; $\mathrm{LF} / \mathrm{NO}=$ low forage no oil; $\mathrm{LF} / \mathrm{O}=$ low forage with oil; RA: rumenic acid. VA: vaccenic acid. $* P<0.05 ; * * P<0.01$.

higher when the ewes were fed soybean oil (Tab. V) and the total amount of all isomers reached the values reported for grazing ewes [29]. In general, all the CLA isomers increased when soybean oil was included in the diet, with the exception of cis-13, trans-15 CLA and cis-12, trans-14 CLA that remained unchanged. The effect of forage/concentrate ratio was significant only for the trans-10, cis-12 CLA isomer. In the case of cis-9, trans-11 CLA (namely rumenic acid, RA); trans-11, cis-13 CLA 
Table V. Effect of forage/concentrate ratio and soybean oil supplementation on CLA isomers in milk (g per $100 \mathrm{~g}$ total lipids).

\begin{tabular}{|c|c|c|c|c|c|c|c|c|}
\hline & \multicolumn{4}{|c|}{ Diets $^{1}$} & \multirow[b]{2}{*}{ SEM } & \multicolumn{3}{|c|}{ Effect } \\
\hline & $\mathrm{HF} / \mathrm{NO}$ & $\mathrm{HF} / \mathrm{O}$ & LF/NO & $\mathrm{LF} / \mathrm{O}$ & & Forage & Oil & For $\times$ Oil \\
\hline Trans-11, trans-13 & 0.018 & 0.027 & 0.013 & 0.024 & 0.002 & & $* *$ & \\
\hline Trans -10, trans -12 & 0.006 & 0.022 & 0.005 & 0.019 & 0.001 & & $* *$ & \\
\hline Trans -9, trans -11 & 0.009 & 0.032 & 0.011 & 0.028 & 0.001 & & $* *$ & \\
\hline Trans -8, trans -10 & 0.011 & 0.018 & 0.010 & 0.019 & 0.002 & & $* *$ & \\
\hline Trans -7, trans -9 & 0.009 & 0.013 & 0.008 & 0.014 & 0.001 & & $* *$ & \\
\hline other trans, trans & 0.006 & 0.011 & 0.005 & 0.012 & 0.001 & & $* *$ & \\
\hline Cis -13 , trans -15 & 0.005 & 0.003 & 0.005 & 0.005 & 0.0001 & & & \\
\hline Cis- 12 , trans -14 & 0.001 & 0.002 & 0.001 & 0.002 & 0.0001 & & & \\
\hline Trans- 11, cis-13 & 0.012 & 0.028 & 0.013 & 0.015 & 0.003 & & * & * \\
\hline Trans -10, cis- 12 & 0.002 & 0.007 & 0.006 & 0.011 & 0.0001 & ** & $* *$ & $*$ \\
\hline Cis -9, trans -11 & 0.386 & 2.224 & 0.582 & 1.806 & 0.296 & & $* *$ & * \\
\hline Cis -8, trans -10 & 0.006 & 0.030 & 0.012 & 0.023 & 0.001 & & $* *$ & \\
\hline Trans-7, cis-9 & 0.026 & 0.083 & 0.034 & 0.103 & 0.009 & & $* *$ & \\
\hline Total CLA isomers & 0.498 & 2.501 & 0.707 & 2.082 & 0.320 & & $* *$ & $*$ \\
\hline
\end{tabular}

${ }^{1}$ Diets: $\mathrm{HF} / \mathrm{NO}=$ high forage no oil; $\mathrm{HF} / \mathrm{O}=$ high forage with oil; $\mathrm{LF} / \mathrm{NO}=$ low forage no oil; $\mathrm{LF} / \mathrm{O}=$ low forage with oil. $* P<0.05 ; * * P<0.01$.

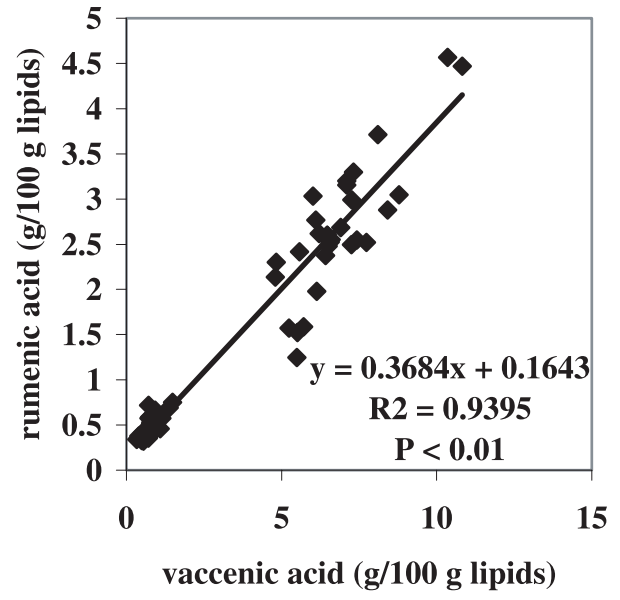

Figure 1. Relationship between the concentration of rumenic acid and vaccenic acid in the milk fat of dairy ewes fed the experimental diets $(n=64)$.

and trans-10, cis-12 CLA the forage $\times$ oil interaction was also significant: the levels of the first two isomers were the highest when the ewes were fed with the HF/O diet, while the last one reached the highest level in milk in response to the $\mathrm{LF} / \mathrm{O}$ diet.

Normalised ratios (g per $100 \mathrm{~g}$ prod$\mathrm{uct} /(\mathrm{g}$ per $100 \mathrm{~g}$ substrate $+\mathrm{g}$ per $100 \mathrm{~g}$ product)) were estimated to asses the extent of $\Delta 9$ desaturation of specific fatty acids during milk fat synthesis [27]. Higher ratios indicated that sheep desaturated more of the substrate fatty acids when they were fed diets without oil supplementation (Tab. IV).

A strictly linear relationship between vaccenic acid and rumenic acid was found (Fig. 1) and the value of the regression coefficient was within the range of values observed in other studies with dairy ewes and other dairy ruminant species $[11,20,26$, 29].

\section{DISCUSSION}

There is a general indication in the literature that the inclusion of unprotected 
oils and fats rich in PUFA in the diet of dairy cows causes a decrease of milk fat yield, known as the Milk Fat Depression (MFD) syndrome, even though some reports do not agree on this [31]. Just the opposite appears to occur with dairy ewes and goats; feed supplementation with plant oils or full fat grains increases their milk fat yield [11]. Such an increase may exceed $2 \%$ with full fat oil seeds [38].

Recently Bauman and Griinari [3] observed that, in order to induce MFD in dairy cows, two conditions must occur: (i) the rumen microbial processes are altered towards acidosis, depending on an unbalanced forage/concentrate ratio and (ii) a significant amount of unsaturated fatty acids (UFA) is present in the diet. There are papers reporting the positive effects on milk fat yield of fatty acid calcium soaps [4] and of high amounts of cotton and sunflower oil [30] in the diet of lactating dairy ewes, but, to our knowledge, no literature information is available so far on the possible interaction between the presence of significant amounts of an unprotected oil and the forage/concentrate ratio on milk fat yield and composition.

In the present study, the milk fat percentage remained unchanged among treatments, while milk fat yield was higher when the unprotected oil was added to the diet, as a consequence of the effect on milk yield. The oil supplement did not induce MFD, regardless of the level of forage, as reported in goat studies [11].

The effects of lipid supplementation on milk yield were in agreement with the literature $[38,46]$. Concerning the level of dietary concentrate on milk production, the results confirmed that during mid- and latelactation, high levels of non-fibre carbohydrates in the diet do not have positive effects on milk yield and quality $[6,7]$.

The decreased milk protein percentage with the oil supplemented diets may be attributed to a combination of factors [31]: (i) the dilution effect due to the higher amount of milk produced per day; (ii) the reduction of microbial protein synthesis with lower dry matter intakes; (iii) changes in the carbohydrate metabolism towards a lower mammary uptake of glucose, as suggested by Smith et al. [43]. Since milk yield was significantly enhanced by oil supplementation in our experiment, the dilution effect may be accounted for to explain the lower protein content. Our results were in agreement with that reported by Zervas et al. [46] with ewes fed $1200 \mathrm{~g} \cdot \mathrm{d}^{-1}$ concentrate and 5\% soybean oil.

Plasma urea data, however, suggested that in the case of a low forage diet, a change in protein utilisation efficiency probably also occurred, as a consequence of the oil supplementation (Tab. III). Nevertheless, among the milk protein fractions, casein did not vary between the treatments.

There are several papers dealing with the effect of the fat source in the diet of cows and goats on the fatty acid pattern of milk fat [11,21], but only few data are available for dairy ewes. The response to feeding lipid supplements rich in PUFA consisted mainly in an increase in the $\mathrm{C} 18$ FA at the expense of SCFA and MCFA (C8 to $\mathrm{C} 14$ mainly). This is probably due to long-chain FA that are powerful inhibitors of de novo lipogenesis in the mammary gland and this effect is more marked when FA have a long chain, are more unsaturated and contain more trans double bonds [12]. In fact, PUFA are biohydrogenated in the rumen into saturated and trans FA, some of which are recognised as potent inhibitors of de novo fatty acid synthesis in the udder [27]. In particular, the trans-10 $\mathrm{C}_{18: 1}$ and trans-10, cis-12 $\mathrm{C}_{18: 2}$ isomers are involved in the MFD syndrome observed in cows, because of their influence upon the mammary lipogenic enzyme activity [4].

Our results (Tab. IV) were in accordance with those reported in the literature on other ruminants but ewes: SCFA and MCFA ( $\mathrm{C}_{6: 0}$ up to $\left.\mathrm{C}_{17: 0}\right)$ were decreased with the oil supplemented diets, but not 
butyric acid; all the $\mathrm{C}_{18: 1}$ isomers augmented, particularly the trans ones. With an oil level in the diet being equal, however, the percentage composition of trans isomer of octadecenoic acid, varied according to the level of dietary forage: vaccenic acid, in fact, seemed to be positively related to high levels of dietary forage $(84.5 \%$ vs. $78 \%$ of total trans isomers for the $\mathrm{HF} / \mathrm{O}$ and $\mathrm{LF} / \mathrm{O}$ diets respectively), while trans-10 C18:1 was the opposite (6.5\% vs. $11.5 \%$ of total trans isomers for the $\mathrm{HF} / \mathrm{O}$ and $\mathrm{LF} / \mathrm{O}$ diets respectively).

In dairy cows, CLA is reported to be enhanced as the consequence of soybean oil supplementation, together with a drop in the milk fat concentration. Then, Kelly et al. [22] succeeded in increasing CLA by $500 \%$ in milk fat of cows fed $5.3 \%$ oil, while the milk fat level fell from $3.38 \%$ down to $2.25 \%$. Dhiman et al. [16] had CLA increased by $300 \%$ and fat percentage down from 3.44 to $2.8 \%$ with only $2 \%$ soybean oil in the diet dry matter.

An interesting finding of the present work was that, unlike cows, the inclusion of soybean oil in the ration of our ewes made rumenic acid jump as high as $500 \%$ with the high forage and $300 \%$ with the low forage diet, but had no apparent effect on the milk fat content (Tab. V). The distribution of CLA isomers also reflected the forage/concentrate ratio in the diet: trans10 , cis-12 reached its maximum with the low forage diet, while the high forage diet accounted for the highest amount of RA. A very similar pattern has been reported by Kukuk et al. [25] who monitored the duodenal flow of fatty acids in sheep fed soybean oil supplemented diets with different forage/concentrate ratios: low forage diets resulted in a larger duodenal flow of unsaturated fatty acids (UFA), including all trans $\mathrm{C}_{18: 1}$ isomers and trans-10, cis-12 CLA, while the highest flow of RA was recorded in response to high forage diets. In dairy cows, Piperova et al. [34] confirmed that the supplementation of low for- age diets with soybean oil has only a slight effect on both RA and VA. Hence, it appears evident that the interaction between the supplemented lipid and the level of forage is of major importance in determining the milk FA composition. With low forage diets, trans $\mathrm{C}_{18: 1}$ is enhanced in milk fat, but the rumen biohydrogenation pathways shift towards trans-10, cis-12 CLA and trans-10 $\mathrm{C}_{18: 1}$, which are accumulated in the rumen and transferred to the udder.

In the present experiment, even though the forage level of the "low forage diets" was not extremely low, the mammary lipogenic enzyme activity appeared altered, as reflected by the lower levels of medium chain fatty acids (MCFA) in milk fat. Nevertheless, the total milk fat yield did not drop, because of the increase in monounsaturated fatty acids (MUFA).

With the unsupplemented diets, the level of RA in the milk fat of our ewes was comparable to the level reported for dairy cows, in Northern Italy [40] and for goats [13], both fed hay based diets, so that it may be assumed that, without the challenge of oil, the differences between the three species are quite small.

Griinari and Bauman [18] proposed the linear regression between VA and RA as a means to estimate the mammary $\Delta 9$ desaturase capacity. Several other authors, reviewed by Chilliard et al. [11,12], used this approach with a large spectrum of diets for cows and goats. The regression coefficient (Fig. 1) calculated from our experimental data falls within the range reported for cows and goats.

The ratios reported in Table IV are commonly used as a proxy for SCD activity. In our study, all the ratios, with the exception of the 18:1/18:1+18:0 one, were significantly higher in milk from ewes fed with unsupplemented diets. Similar results were also reported for dairy goats fed a hay based diet unsupplemented or supplemented with $3.6 \%$ lipid of formaldehyde linseed or oleic sunflower oil [5]. 
In the present study, in ewes, a huge individual variability in milk CLA content may be observed, especially with the oil supplemented diets, similar to what is reported for dairy cows [26,33], (Tab. V): the higher the availability of VA to the mammary gland, the larger the variability between the individuals.

\section{CONCLUSION}

The role of dietary lipid supplementation is well known in dairy cows and goats, but only scarce information is available with reference to the effect of unprotected vegetable oils and to their interaction with the level of forage in the ration of dairy ewes. The present paper may answer some questions on the subject.

First, the supplementation with unprotected soybean oil increased both milk yield and milk fat, with no adverse effect on the cheese making ability of milk. Since sheep milk is completely used to make cheese, this result is of practical importance in the feeding strategy of dairy ewes. Dietary lipid supplementation is usually adopted during early lactation, but our results suggest that the inclusion of a fat source to the diet may adequately support milk production also in mid lactation. On the contrary, in this phase of lactation high levels of concentrate in the ration do not seem advisable.

Second, the supplemented oil exerted a strong and important effect on the fatty acid composition of milk fat: saturated FA, pointed out for their negative effects on human health, were depressed, whereas MUFA, PUFA and rumenic acid, with potential positive effects, were enhanced. In particular, the interaction between oil and forage level significantly affected the composition of cis and trans $\mathrm{C}_{18: 1}$ isomers. Also in dairy ewes, by increasing the concentrate component of the diet, the rumen biohydogenation pathways are shifted to- wards more trans-10 $\mathrm{C}_{18: 1}$ and more trans10, cis-12 CLA, apparently with no negative effects on milk fat yield, according to what was observed in goats.

\section{ACKNOWLEDGEMENTS}

The research was supported by the Italian Ministero delle Politiche Agricole e Forestali (MIPAF), D.M. 535/7303/02, 29/11/2002 and by the Agenzia Regionale per lo Sviluppo e Innovazione in Agricoltura of Tuscany (ARSIA).

\section{REFERENCES}

[1] Antongiovanni M., Secchiari P., Mele M., Buccioni A., Serra A., Ferruzzi G., Rapaccini S., Pistoia A., Olive oil calcium soaps and rumen protected methionine in the diet of lactating ewes: effect on milk quality, Ital. J. Anim. Sci. 1 (2002) 55-64.

[2] Association of Official Analytical Chemist, Official Methods of Analysis of the AOAC, 15th ed., AOAC Arlington, VA, USA, 1990.

[3] Bauman D.E., Griinari J.M., Regulation and nutritional manipulation of milk fat: low-fat milk syndrome, Livest. Prod. Sci. 70 (2001) 15-30.

[4] Baumgard L.H., Matitashvili E., Corl B.A., Dwyer D.A., Bauman D.E., trans-10, cis-12 conjugated linoleic acid decreases lipogenic rates and expression of genes involved in milk lipid synthesis in dairy cows, J. Dairy Sci. 85 (2002) 2155-2163.

[5] Bernard L., Rouel J., Leroux C., Ferlay A., Faulconnier Y., Legrand P., Chilliard Y., Mammary lipid metabolism and milk fatty acid secretion in Alpine goats fed vegetable lipids, J. Dairy Sci. 88 (2005) 1478-1489.

[6] Bocquier F., Caja G., Production et composition du lait de brebis : effets de l'alimentation, INRA Prod. Anim. 14 (2001) 129-140.

[7] Cannas A., Feeding of lactating ewes, in: Pulina G. (Ed.), Dairy Sheep Feeding and Nutrition, Avenue Media, Bologna, Italy, 2002, pp. 123-166.

[8] Cannas A., Tedeschi L.O., Fox D.G., Pell A.N., Van Soest P.J., A mechanistic model for predicting the nutrients requirements and feed biological values for sheep, J. Anim. Sci. 82 (2004) 149-169. 
[9] Casals R., Caja G., Such X., Torre C., Calsamiglia S., Effects of calcium soaps and rumen undegradable protein on the milk production and composition of dairy ewes, J. Dairy Res. 66 (1999) 177-191.

[10] Chilliard Y., Bocquier F., Effect of fat supplementation on milk yield and composition in dairy goats and ewes, in: Proceedings of the 5th International Symposium "La qualità delle produzioni dei piccolo ruminanti", Camera di Commercio, Industria, Artigianato e Agricoltura di Varese, Italy, 1993, pp. 61-78.

[11] Chilliard Y., Ferlay A., Rouel J., Lamberet G., A review of nutritional and physiological factors affecting goat milk lipid synthesis and lipolysis, J. Dairy Sci. 86 (2003) 17511770.

[12] Chilliard Y., Ferlay A., Mansbridge R.M., Doreau M., Ruminant milk fat plasticity: nutritional control of saturated, polyunsaturated, trans and conjugated fatty acids, Ann. Zootech. 49 (2000) 161-292.

[13] Chilliard Y., Chabosseau J.M., Rouel J., Capitan P., Gominard C., Gaborit P., Juaneda P., Ferlay A., Interactions between forage nature and sunflower or linseed oil supplementation on goat milk fatty acids of interest for human nutrition, in: Durans J.L., Emile J.C., Huyghe C., Lemaire G. (Eds.), Multi-function Grasslands: quality forages, animal products and Landscapes, Vol. 7, Proceedings of 19th General Meeting of the European Grassland Federation, La Rochelle, France, Grassland Science in Europe, 2002, pp. 548-549.

[14] Christie W.W., A simple procedure of rapid transmethylation of glycerolipids and cholesteryl esters, J. Lipid Res. 23 (1982) 1072-1075.

[15] Delacroix-Buchet A., Barillet F., Lagriffoul G., Caractérisation de l'aptitude fromagère des laits de brebis Lacaune à l'aide d'un Formagraph, Le lait 74 (1994) 173-186.

[16] Dhiman T.R., Satter L.D., Pariza M.W., Galli M.P., Albright K., Tolosa M.X., Conjugated linoleic acid (CLA) content of milk from cows offered diets rich in linoleic and linolenic acid, J. Dairy Sci. 83 (2000) 10161027.

[17] Goering H.K., Van Soest P.J., Forage fibre analysis (apparatus, reagents, procedures and some applications), Agric. Handbook No. 379, Agric. Res. Service, USDA, Washington, DC, 1970.

[18] Griinari J.M., Bauman D.E., Biosynthesis of conjugated linoleic acid and its incor- poration into meat and milk in ruminants, in: Yurawecz M.P., Mossoba M.M., Kramer J.K.G., Pariza M.W., Nelson G.J. (Eds.), Advances in Conjugated linoleic acid research, Vol. 1, AOCS Press, Champaign, IL, 1999, pp. 180-200.

[19] Hadjipanayiotou M., Feeding ensiled crude olive cake to lactating Chios ewes, Damascus goats and Friesian cows, Livest. Prod. Sci. 59 (1999) 61-66.

[20] Jahreis G., Fritsche J., Steinhart H., Conjugated linoleic acid in milk fat: high variation depending on production system, Nutr. Res. 17 (1997) 1479-1484.

[21] Jensen R.G., The composition of bovine milk lipids: January 1995 to December 2000, J. Dairy Sci. 85 (2002) 295-350.

[22] Kelly M.L., Berry J.R., Dwyer D.A., Griinari J.M., Chouinard P.Y., Van Amburgh M.E., Bauman D.E., Dietary fatty acid sources affect conjugated linoleic acid concentrations in milk from lactating dairy cows, J. Nutr. 128 (1998) 881-885.

[23] Kitessa S.M., Gulati S.K., Ashes J.R., Fleck E., Scott T.W., Nichols P.D., Utilisation of fish oil in ruminants. I. Fish oil metabolism in sheep, Anim. Feed Sci. Tech. 89 (2001) 189-199.

[24] Kramer J.K.G., Cruz-Hernandez C., Deng Z.Y., Zhou J.Q., Jahreis G., Dugan M.E.R., Analysis of conjugated linoleic acid and trans 18:1 isomers in synthetic and animal products, Am. J. Clin. Nutr. 79 (2004) 1137S-1145S.

[25] Kukuk O., Hess B.W., Ludden P.A., Rule D.C., Effect of forage/concentrate ratio on ruminal digestion and duodenal flow of fatty acids in ewes, J. Anim. Sci. 79 (2001) 22332240.

[26] Lawless F., Murphy J.J., Harrington D., Devery R., Stanton C., Elevation of conjugated cis-9, trans-11 octadecadienoic acid in bovine milk because of dietary supplementation, J. Dairy Sci. 81 (1998) 3259-3267.

[27] Loor J.J., Herbein J.H., Reduced fatty acid synthesis and desaturation due to exogenous trans10, cis12 - CLA in cows fed oleic or linoleic oil, J. Dairy Sci. (2003) 1354-1369.

[28] Molkentin J., Precht D., Validation of a gaschromatographic method for the determination of milk fat contents in mixed fats by butyric acid analysis, Eur. J. Lipid Sci. Tech. 102 (2000) 194-201.

[29] Nudda A., Mele M., Battacone G., Usai M.G., Macciotta N.P.P., Comparison of conjugated linoleic acid (CLA) content in milk 
of ewes and goats with the same dietary regimen, Ital. J. Anim. Sci. (Suppl. 1) (2003) 515-517.

[30] Osuna D.R., Casals R., Caja G., Peris S., Effect of feeding whole oilseeds to partially replace calcium soap of fatty acids on dairy ewes intake and milk production and composition, J. Dairy Sci. 81 (Suppl. 1) (1998) 302.

[31] Palmquist D.L., Jenkins T.C., Fat in lactation rations: review, J. Dairy Sci. 63 (1980) 1-25.

[32] Perez-Alba L.M., de Souza Cavalcanti S., Perez Hernandez M., Martinez Marin A. Fernandez Marin G., Calcium soap of olive fatty acids in the diet of Manchega dairy ewes: effect on digestibility and production, J. Dairy Sci. 80 (1997) 3316-3324.

[33] Peterson D.G., Kelsey J.A., Bauman D.E., Analysis of variation in cis-9, trans-11 conjugated linoleic acid (CLA) in milk fat of dairy cows, J. Dairy Sci. 85 (2002) 2164-2172.

[34] Piperova L.S., Teter B.B., Bruckental I., Sampugna J., Mills S.E., Yurawecz M.P., Fritsche J., Ku K., Erdman R.A., Mammary lipogenic enzyme activity, trans fatty acids and conjugated linoleic acids are altered in lactating dairy cows fed a milk fatdepressing diet, J. Nutr. 130 (2000) 26582674.

[35] Pulina G., Nudda A., Milk production, in: Pulina G. (Ed.), Dairy Sheep Feeding and Nutrition, Avenue Media, Bologna, Italy, 2002, pp. 11-27.

[36] Rotunno T., Sevi A., Di Caterina R., Muscio A., Effects of graded levels of dietary rumen protected fat on milk characteristics of Comisana ewes, Small Rum. Res. 30 (1998) 137-145.

[37] SAS User's Guide: Statistics, Version 8.0 Edition, SAS Inst. Inc., Cary, NC, 1999.

[38] Schmidely P., Sauvant D., Taux butyreux et composition de la matière grasse du lait chez les petits ruminants : effets de l'apport de matière grasses ou d'aliment concentré, INRA Prod. Anim. 14 (2001) 337-354.

[39] Secchiari P., Antongiovanni M., Mele M., Serra A., Buccioni A., Ferruzzi G., Paoletti F., Petacchi F., Effect of kind of dietary fat on quality of milk fat from Italian Friesian cows, Livest. Prod. Sci. 83 (2003) 43-52.

[40] Secchiari P., Mele M., Serra A., Buccioni A., Paoletti F., Antongiovanni M., Effect of breed, parity and stage of lactation on milk conjugated linoleic acid content in Italian Friesian and Reggiana cows, Ital. J. Anim. Sci. 2 (Suppl. 1) (2003) 269-271.

[41] Sehat N., Yurawecz M.P., Roach J.A.G., Mossoba M.M., Kramer J.K.G, Ku K., Silver ion High Performance Liquid Chromatographic separation and identification of conjugated linoleic acid isomers, Lipids 33 (1998) 217-221.

[42] Sevi A., Rotunno T., Di Caterina R., Muscio A., Rumen protected methionine or lysine supplementation of Comisana Ewes diets: effects on milk fatty acid composition, J. Dairy Res. 65 (1998) 413-422.

[43] Smith N.E., Dunkley W.L., Franke A.A. Effects of feeding protected tallow to dairy cows in early lactation, J. Dairy Sci. 61 (1978) 747-756.

[44] Wiggans G.R., Shook G., A lactation measure of somatic cell count, J. Dairy Sci. 70 (1987) 2666-2672.

[45] Wolff R.L., Bayard C.C., Improvement in the resolution of individual trans-18:1 isomers by capillary gas liquid chromatography: use of a $100 \mathrm{~m}$ CP-Sil 88 column, JAOCS 72 (1995) 1197-1201.

[46] Zervas G., Fegeros K., Koytstolis K., Goulas C., Mantzios A., Soy hulls as a replacement for maize in lactating dairy ewe with or without dietary fat supplements, Anim. Feed Sci. Tech. 76 (1998) 65-75.

To access this journal online: www.edpsciences.org 